\begin{tabular}{ccc} 
Tersedia online di: http://ejournal-balitbang.kkp.go.id/index.php/jppi & JURNAL \\
e-mail:jppi.puslitbangkan@ gmail.com & PENELTIAN \\
PERIKANAN & INDONESIA \\
JURNALPENELITIANPERIKANANINDONESIA & Volume 24 Nomor 1 Maret 2018 \\
p-ISSN: 0853-5884 & e-ISSN: 2502-6542 \\
Nomor Akreditasi: 653/AU3/P2MI-LIPI/07/2015 & \\
\hline
\end{tabular}

\title{
PERTUMBUHAN, HASIL PER PENAMBAHAN BARU DAN RASIO POTENSI PEMIJAHAN IKAN KAKAP MERAH (Lutjanus malabaricus Schneider, 1801) DI PERAIRAN SINJAI DAN SEKITARNYA
}

\section{GROWTH, YIELD PER RECRUIT AND SPAWNING POTENTIAL RATIO OF RED SNAPPER (Lutjanus malabaricus Schneider, 1801) IN SINJAI AND ADJACENT WATERS}

\author{
Tirtadanu ${ }^{* 1}$, Karsono Wagiyo ${ }^{1}$ dan Bambang Sadhotomo ${ }^{1}$ \\ 'Balai Riset Perikanan Laut, Kompl. Raiser JI. Raya Bogor KM. 47 Nanggewer Mekar, Cibinong, Bogor \\ Teregistrasi I tanggal: 18 Agustus 2017; Diterima setelah perbaikan tanggal: 21 Desember 2017; \\ Disetujui terbit tanggal: 29 Desember 2017
}

\begin{abstract}
ABSTRAK
Pengusahaan ikan kakap merah (Lutjanus malabaricus Schneider, 1801) sebagai salah satu bisnis perikanan utama di Sinjai memerlukan informasi tingkat pemanfaatan sebagai dasar dalam merumuskan pengelolaan yang tepat. Penelitian ini bertujuan untuk mengkaji pertumbuhan, hasil per penambahan baru dan estimasi rasio potensi pemijahan ikan kakap merah di perairan Sinjai dan sekitarnya. Penelitian dilakukan pada Januari - November 2016 dengan pengukuran sampel ikan dilakukan oleh enumerator di Sinjai. Analisis hasil per penambahan baru menggunakan metode Beverton \& Holt dan analisis rasio potensi pemijahan menggunakan metode berbasis panjang (Length Based SPR). Hasil penelitian menunjukkan ikan kakap merah memiliki panjang asimptotik 77,3 cm dan laju pertumbuhan 0,293 tahun ${ }^{-1}$. Tingkat pemanfaatan (E) sebesar 0,35 dan upaya penangkapan $(F)$ lebih kecil dari titik acuan $\left(F_{\text {cur }}=0,25 ; F_{\text {max }}=1,2 ; F_{0,1}=0,9\right)$ pada ukuran rata-rata pertama tertangkap (Lc) sebesar $38,1 \mathrm{~cm}$, menunjukkan upaya penangkapan mendekati optimum dan masih dapat dikembangkan. Estimasi rasio pemijahan sebesar $51 \%$ pada panjang rata-rata $48,17 \mathrm{~cm}$ TL lebih besar dari titik referensi minimum ikan kakap sebesar $26 \%$. Pengelolaan yang disarankan berdasarkan penelitian ini adalah upaya pengusahaan kakap merah dapat dikembangkan hingga 30\% dari upaya saat ini dengan diikuti oleh pengaturan ukuran ikan tertangkap lebih besar dari ukuran pertama kali memijah yaitu sebesar $45 \mathrm{~cm}$.
\end{abstract}

Kata Kunci: Kakap merah; potensi rasio pemijahan; hasil per penambahan baru; perairan Sinjai dan sekitarnya

\begin{abstract}
Red snapper (Lutjanus malabaricus Schneider, 1801) fishing as one of the main fisheries business in Sinjai need information on exploitation level as basis for formulating proper management. The aims of this research were to study growth, yield per recruit and spawning potential ratio (SPR) of red snapper in Sinjai and adjacent waters. This research was conducted in January - November 2016 and fish samples were measured by enumerator. Yield per recruit analysis used Beverton \& Holt method and spawning potential ratio analysis used length based $S P R$. The results showed that the asymptotic length was $77,3 \mathrm{~cm}$ and the growth parameter of red snapper was 0,293 year ${ }^{-1}$. Exploitation rate $(E)$ was 0,35 and fishing effort $(F)$ less than reference point $\left(F_{\text {cur }}=0,25, ; F_{\max }=1,2 ; F_{0,1}=0,9\right)$ on size at first captured $(L C) 38,1 \mathrm{~cm}$, indicating fishing effort has closed to optimum and can be developed. Spawning potential ratio was $51 \%$, with $48,17 \mathrm{~cm} T \mathrm{~L}$ of
\end{abstract}


mean size, larger than limit reference point that was $26 \%$. Recommended management measures based on this research were that fishing effort of red snapper can be increased until $30 \%$ from current effort followed by size regulation to catch above size at first matured at $45 \mathrm{~cm}$.

\section{Keywords: Red snapper; spawning potential ratio; yield per recruit; Sinjai and adjacent waters}

\section{PENDAHULUAN}

Ikan kakap merah (Lutjanus malabaricus Schneider, 1801) merupakan salah satu komoditas perikanan demersal dari Ordo Perciformes dan Famili Lutjanidae yang hidup di dekat dasar perairan pantai maupun lepas pantai pada kedalaman 12-100 m (FAO, 1998). Penyebaran ikan kakap merah berada di sekitar perairan Kepulauan Indonesia dan Pasifik Barat, Korea dan perairan Barat Atlantik dengan jenis substrat yang berkarang dan berlumpur (FAO, 1998; Kim et al., 2012; Gold et al., 2011). Salah satu perairan di Indonesia yang potensial bagi pengusahaan ikan kakap merah yaitu di perairan Sinjai, Provinsi Sulawesi Selatan dan sekitarnya.

Ikan kakap merah merupakan salah satu komoditas unggulan bagi bisnis perikanan di Sinjai, Provinsi Sulawesi Selatan karena nilai ekonomi yang tinggi dan telah dipasarkan baik di pasar lokal maupun diekspor. Alat tangkap dominan yang digunakan oleh nelayan untuk menangkap ikan kakap merah di perairan Sulawesi Selatan termasuk Sinjai adalah pancing rawai dasar. Pada tahun 2014, jumlah armada rawai dasar di Provinsi Sulawesi Selatan sebanyak 7.966 unit dengan besaran produksi tertinggi keempat setelah Provinsi Papua, Maluku dan Jawa Timur dan total produksi kakap merah tercatat sebanyak 7.420 ton (Direktorat Jenderal Perikanan Tangkap, 2015).

Pengusahaan ikan kakap merah di daerah Sinjai Provinsi Sulawesi Selatan memerlukan informasi terkait tingkat pemanfaatannya sebagai dasar dalam menentukan pengelolaan yang tepat. Beberapa model yang dapat digunakan dalam menentukan tingkat pemanfaatannya berdasarkan data ukuran panjang adalah hasil per penambahan baru dan estimasi rasio pemijahan (Beverton \& Holt, 1957; Goodyear, 1993). Penelitian ini bertujuan untuk mengkaji parameter pertumbuhan, hasil per penambahan baru dan estimasi rasio pemijahan ikan kakap merah di perairan Sinjai dan sekitarnya. Hasil kajian ini dapat digunakan sebagai salah satu dasar pengelolaan ikan kakap merah yang tepat, khususnya di perairan Sinjai dan sekitarnya.

\section{BAHAN DAN METODE Pengumpulan Data}

Penelitian ini dilakukan di tempat pendaratan ikan di Kabupaten Sinjai, Provinsi Sulawesi Selatan pada Januari-November 2016. Sampel ikan kakap merah (Lutjanus malabaricus Schneider, 1801) merupakan hasil tangkapan nelayan yang beroperasi di sekitar perairan Sinjai, Takalala, Teluk Bone dan Pulau Sembilan (Gambar 1). Alat tangkap yang digunakan untuk menangkap ikan kakap merah adalah rawai dasar dan pancing ulur dengan mata pancing ukuran nomor 4 dan menggunakan umpan bulu sutera. Pengukuran ikan kakap merah dilakukan setiap bulan oleh enumerator dan data yang dikumpulkan meliputi panjang total (Total Length $=T L$ ), berat dan Tingkat Kematangan Gonad (TKG). Sampel ikan yang diukur sebanyak 479 ekor yang terdiri dari 206 ekor jantan dan 273 ekor betina. Panjang total diukur dengan mistar dengan satuan $\mathrm{cm}$ dan ketelitian $0,1 \mathrm{~cm}$. Berat ikan diukur dengan timbangan dengan satuan $\mathrm{kg}$ dengan ketelitian 0,1 kg. Tingkat Kematangan Gonad terdiri dari TKG I (immature), TKG II (early maturing), TKG III (late maturing), TKG IV (ripe) dan TKG IV (spawning) diduga dari ciri gonad dan ovarium berdasarkan Schaefer \& Orange (1956). 


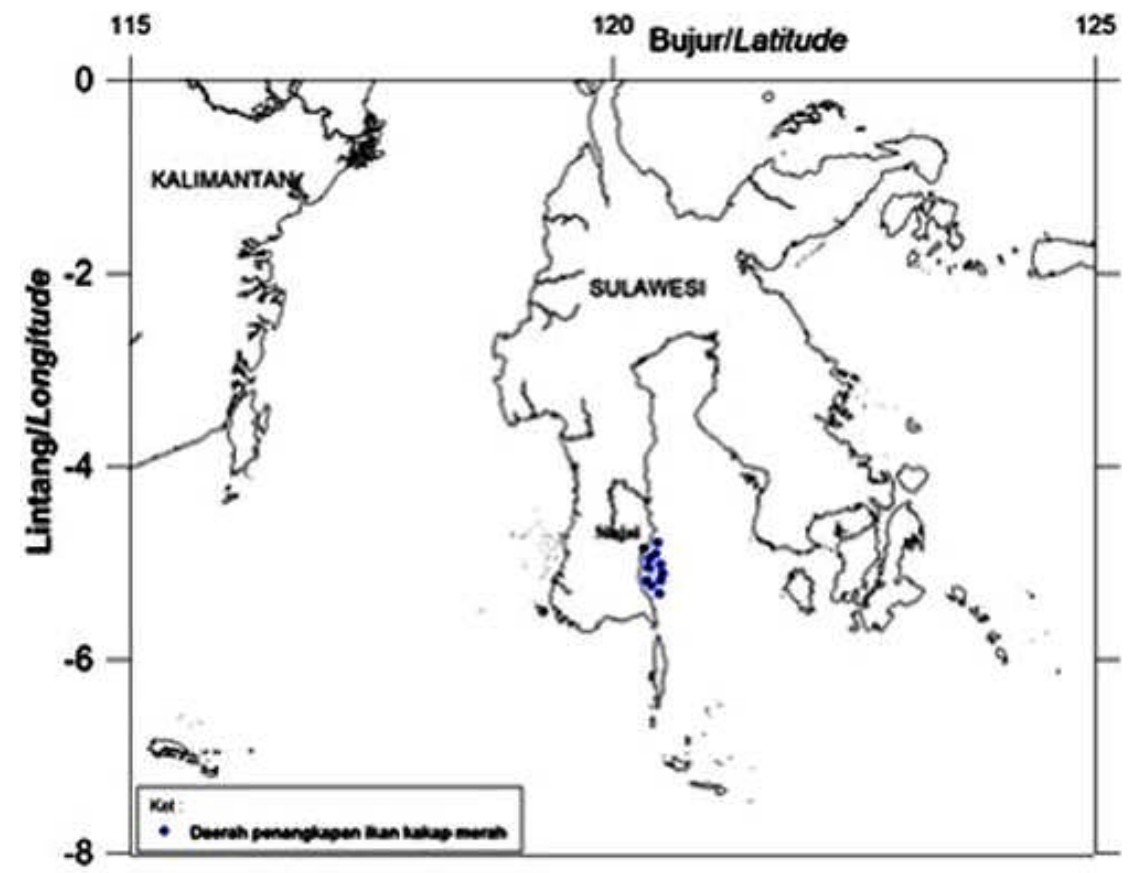

Gambar 1. Daerah penangkapan kakap merah di perairan Sinjai dan sekitarnya.

Figure 1. Fishing ground of red snapper in Sinjai waters and adjacent waters.

\section{Analisis Data}

Analisis data dilakukan untuk memperoleh informasi sebaran frekuensi ukuran, panjang rata-rata pertama kali matang gonad $(\mathrm{Lm})$, ukuran rata-rata pertama kali tertangkap (LC), pertumbuhan, hasil per penambahan baru dan estimasi rasio pemijahan ikan kakap merah. Frekuensi ukuran panjang disajikan dalam grafik batang dengan interval kelas $2 \mathrm{~cm}$.

Rata-rata panjang pertama kali matang gonad $(\mathrm{Lm})$ diperoleh dengan membandingkan proporsi ikan kakap merah matang gonad (TKG III, TKG IV dan TKG V) dengan belum matang (TKG I dan TKG II) berdasarkan ukuran panjang total dan dianalisis berdasarkan grafik fungsi logistik (King, 1995) dengan persamaan:

$$
P_{L m}=\frac{1}{1+\exp (a L+b)}
$$

Rata-rata panjang pertama kali tertangkap (LC) diperoleh melalui pendekatan fungsi logistik dengan persamaan (Sparre \& Venema, 1992):

$$
S_{L}=\frac{1}{1+\exp \left(a-b^{*} L\right)}
$$

Dimana: $S_{L}$ adalah selektivitas alat tangkap, a dan $b$ adalah konstanta, $L$ adalah panjang ikan dan nilai Lc diperoleh dari a/b.

Pola pertumbuhan diduga menggunakan model pertumbuhan von Bertalanffy (Sparre \& Venema, 1992):

$$
L_{t}=L \infty\left[1-e^{-K(t-t)}\right]
$$

$\mathrm{L}_{t}$ adalah panjang total ikan saat $u$ mur $t, \mathrm{~L}_{\infty}$ adalah rata-rata panjang maksimum ikan dalam suatu populasi, $\mathrm{K}$ adalah laju pertumbuhan dan $\mathrm{t}_{0}$ adalah umur teoritis saat panjang ikan nol. Panjang asimptotik $\left(\mathrm{L}_{\infty}\right)$ dan laju pertumbuhan $(\mathrm{K})$ diduga dengan metode ELEFAN dalam paket TropFishR menggunakan program $R$ (Mildenberger et al., 2017). Nilai $t_{0}$ (umur pada saat panjang 0 ) diduga berdasarkan persamaan Pauly (1983) yaitu:

$$
\log \left(-t_{0}\right)=(-0,3922)-0,2752 \log L_{\infty}-1,038 \log K \ldots(4)
$$

Kematian alami ikan (M) diduga dengan metode Chen \& Watanabe (1989) dengan persamaan:

$$
\begin{gathered}
M(t)=\frac{k}{\left(1-e^{-k\left(t-t_{0}\right)}\right)}, \text { jika } \mathrm{t}<\mathrm{t}_{\mathrm{m}} \ldots \ldots \ldots \ldots \ldots \ldots \ldots . . . . . . . . \\
M(t)=\frac{k}{a_{0}+a_{1}\left(t-t_{m}\right)+a_{2}\left(t-t_{m}\right)}, \text { jika } \mathrm{t}>\mathrm{t}_{\mathrm{m}} \ldots \ldots
\end{gathered}
$$

Dimana: $\mathrm{M}$ adalah laju kematian alami dan $\mathrm{t}_{\mathrm{m}}$ diperoleh dari $t_{m}=-\frac{1}{k} \ln \left|1-e^{k t_{0}}\right|+t_{0}$.

Estimasi rasio potensial pemijahan atau Spawning Potential Ratio (SPR) diperoleh dengan metode berbasis data panjang (Length based SPR) (Hordyk 
et al., 2015). Nilai SPR ikan akan tinggi jika ikan berukuran besar, tertangkap dalam jumlah yang banyak dan sebaliknya SPR rendah jika ikan berukuran besar atau lebih besar dari ukuran matang gonad, tertangkap dalam jumlah yang sedikit (Hordyk et al., 2015; Prince et al., 2015). Data input yang digunakan dalam analisis SPR adalah rasio $\mathrm{M} / \mathrm{K}$, panjang asimptotik $\left(\mathrm{L}_{\infty}\right)$, proporsi $50 \%$ populasi matang gonad (Lm), proporsi $95 \%$ populasi matang gonad $\left(\mathrm{Lm}_{95}\right)$ dan panjang ikan.

Hasil per penambahan baru ikan kakap merah dianalisis berdasarkan metode Beverton \& Holt (1957):

$$
\frac{Y}{R}=F * A * W \infty *\left(\frac{1}{Z}-\frac{3 U}{Z+K}+\frac{3 U^{2}}{Z+2 K}+\frac{U^{3}}{Z+3 K}\right) \ldots \ldots \ldots(7)
$$

dimana $\mathrm{F}$ adalah laju kematian karena penangkapan,

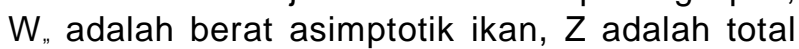
kematian, $\mathrm{K}$ adalah laju pertumbuhan, A merupakan hasil dari persamaan $A=\left[\frac{L_{\infty}-L_{c}}{L_{\infty}-L_{r}}\right]^{M / K}$ dan $U$ diperoleh dari persamaan $U=1-\frac{L c}{L \infty}$. Analisis biomasa per penambahan baru $(\mathrm{B} / \mathrm{R})$ diperoleh dari persamaan (Sparre \& Venema,):

$$
\frac{B}{R}=\frac{Y}{R} * \frac{1}{F}
$$

Titik acuan $\left(\mathrm{F}_{0,1}\right)$ berdasarkan Gulland \& Boerema (1973) merupakan laju kematian karena penangkapan (F) saat hasil per penambahan baru sama dengan $10 \%$ dari biomasa awal atau dengan persamaan $\mathrm{V}=\mathrm{Y}$ $0,1{ }^{*} \mathrm{~B}_{0}{ }^{*} \mathrm{~F}$ di mana nilai $\mathrm{Y}$ merupakan hasil per penambahan baru maksimum $\left(\mathrm{Y} / \mathrm{R}_{\max }\right)$, F sebagai variabel independen dan $V$ sebagai variabel dependen (Cadima, 2003). Titik acuan $\left(F_{0,1}\right)$ diperoleh dari hasil analisis persamaan regresi yaitu $-\mathrm{b} / 2 \mathrm{a}$ berdasarkan hubungan upaya penangkapan $(F)$ sebagai variabel independen dan nilai $V$ sebagai variabel dependen .

\section{HASIL DAN BAHASAN \\ Hasil}

\section{Parameter Biologi}

Ukuran panjang total ( Total Length=TL) ikan kakap merah (Lutjanus malabaricus Schneider, 1801) yang tertangkap di sekitar perairan Sinjai berkisar antara $30-74 \mathrm{~cm}$ dengan modus berada pada ukuran 50 cm TL (Gambar 2). Rata-rata ukuran panjang total (TL) ikan kakap merah yang tertangkap pada periode Januari-November 2016 adalah 48,17 \pm 0,9 cmTL.

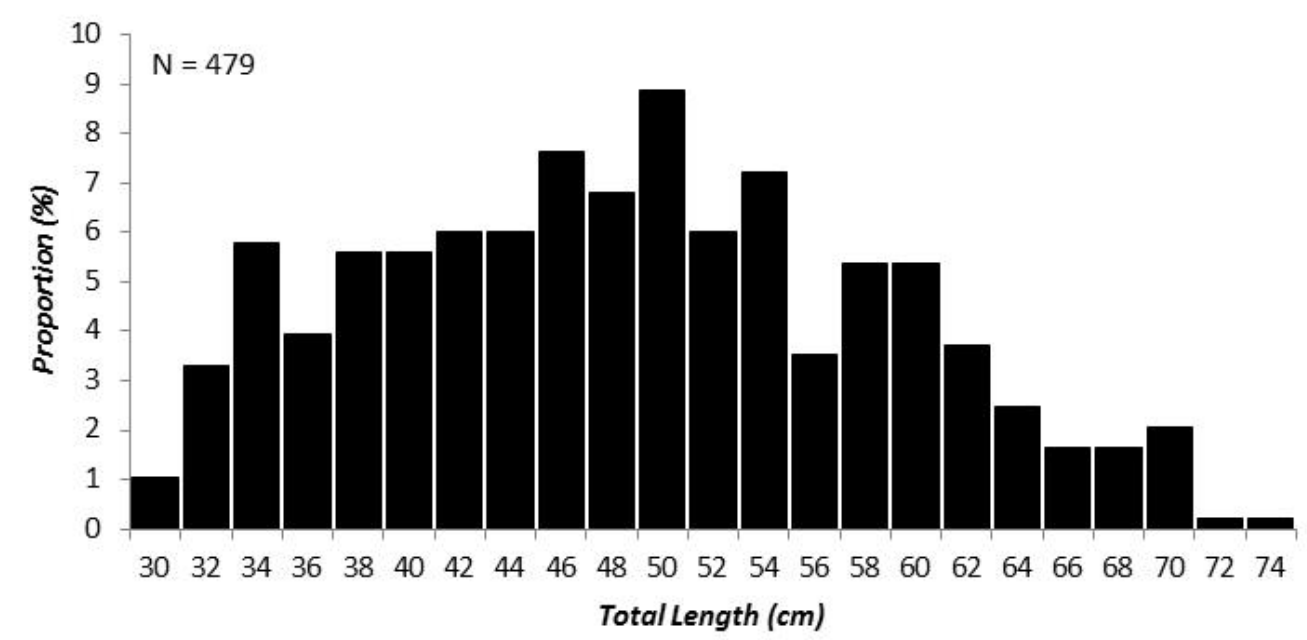

Gambar 2. Sebaran frekuensi panjang total ikan kakap merah (L. malabaricus) tertangkap di perairan Sinjai dan sekitarnya.

Figure 2. Total Length (TL) frequency distribution of red snapper (L. malabaricus) caught in Sinjai waters and adjacent.

Hubungan panjang dengan berat ikan kakap merah di perairan Sinjai dan sekitarnya mengikuti persamaan $\mathrm{W}=0,00001^{*} \mathrm{~L}^{2,9997}$. Pola pertumbuhan ikan kakap merah berdasarkan uji-t dengan tingkat kepercayaan $95 \%(a ́=0,05)$ adalah isometrik atau nilai b=3. Kondisi tersebut menunjukkan pertambahan panjang ikan kakap merah sama dengan beratnya (Gambar 3).
Panjang rata-rata pertama kali tertangkap (LC) ikan kakap merah di perairan Sinjai dan sekitarnya adalah $38,1 \mathrm{~cm}$. Panjang rata-rata pertama kali matang gonad (Lm) ikan kakap merah di perairan Sinjai dan sekitarnya adalah 45,6 cm (Gambar 4). 


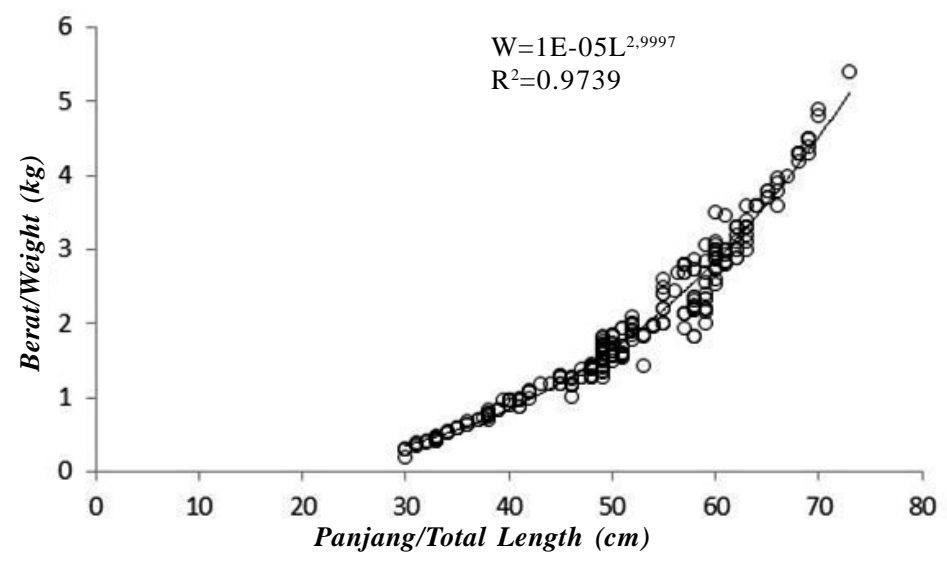

Gambar 3. Hubungan panjang-berat ikan kakap merah (Lutjanus malabaricus) di perairan Sinjai dan sekitarnya. Figure 3. Length-weight relationship of red snapper (L. malabaricus) in Sinjai waters and adjacent.

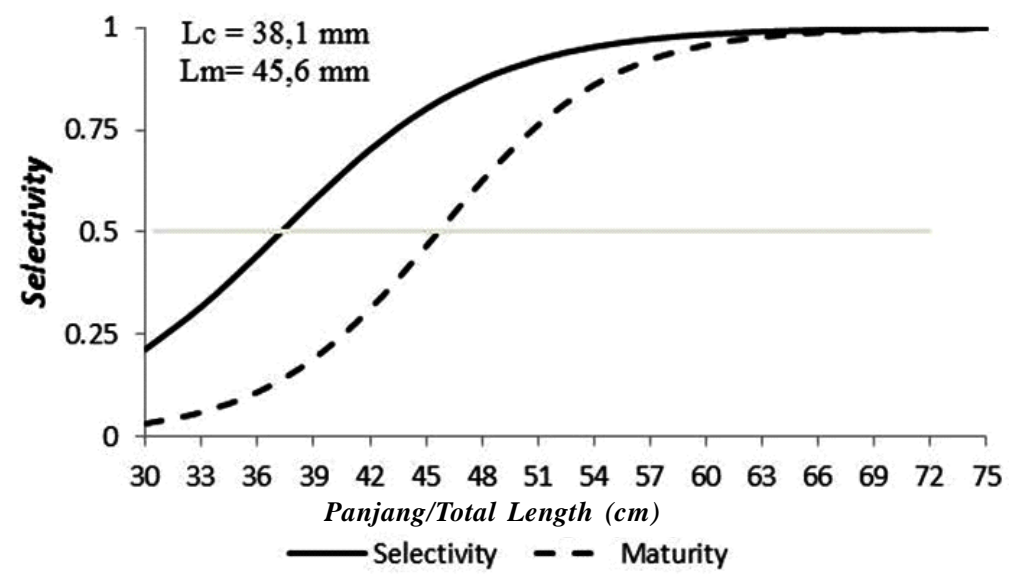

Gambar 4. Ukuran rata-rata pertama kali tertangkap (Lc) dan ukuran rata-rata pertama kali matang gonad (Lm) ikan kakap merah (L. malabaricus) tertangkap di perairan Sinjai dan sekitarnya.

Figure 4. Length at first captured (LC) and length at first matured ( $L m)$ of red snapper (L. malabaricus) caught in Sinjai waters and adjacent.

\section{Pola Pertumbuhan}

Panjang asimptotik ikan kakap merah di perairan Sinjai dan sekitarnya diperkirakan mencapai $77,3 \mathrm{~cm}$ dengan laju pertumbuhan $(\mathrm{K})$ adalah 0,293 tahun $^{-1}$ serta umur teoritis pada saat panjang ikan sama dengan nol $\left(\mathrm{t}_{0}\right)$ adalah 0,034 tahun sehingga diperoleh persamaan pertumbuhan $\mathrm{L}(\mathrm{t})=77,3\left[1-\mathrm{e}^{-0,293(t+0,34)}\right]$ (Gambar 5). Ikan kakap merah mencapai ukuran maksimum diduga pada umur 10 tahun. Ukuran ratarata pertama kali matang gonad ikan kakap $\left(\mathrm{Lm}_{50}\right)$ sebesar 45,6 cm diduga dicapai pada umur 3 tahun.

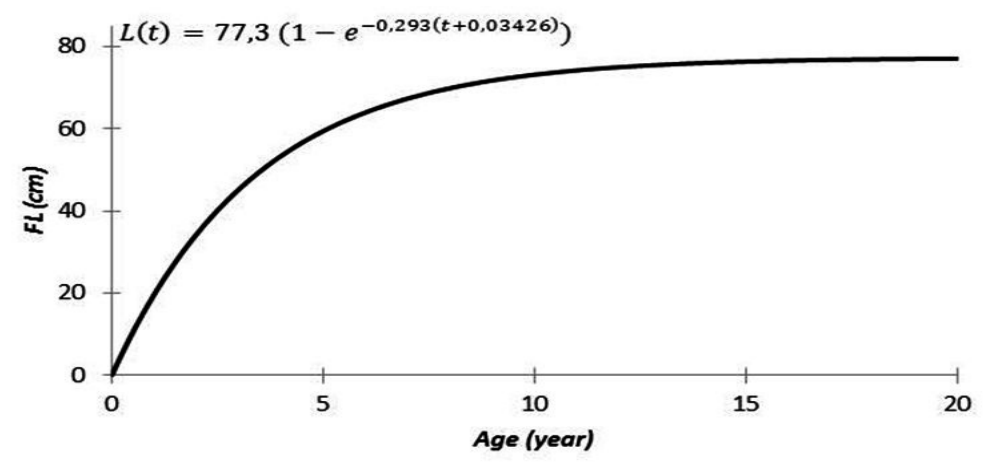

Gambar 5. Kurva pertumbuhan Von Bertalanffy ikan kakap merah (L. malabaricus) tertangkap di perairan Sinjai dan sekitarnya.

Figure 5. Von Bertalanffy Growth Curve of red snapper (L. malabaricus) caught in Sinjai waters and adjacent. 


\section{Laju Kematian dan Tingkat Pemanfaatan}

Laju kematian alami (M) ikan kakap merah di perairan Sinjai dan sekitarnya yang dianalisis berdasarkan metode Chen \& Watanabe (1989) adalah 0,47 tahun $^{-1}$. Laju kematian karena penangkapan $(F)$ diperoleh sebesar 0,25 tahun $^{-1}$ sehingga diperoleh laju kematian total (Z) adalah 0,72 tahun $^{-1}$. Laju kematian karena penangkapan lebih rendah dibandingkan laju kematian alami sehingga laju pengusahaan $(E)$ lebih rendah dari 0,5 atau sebesar 0,35 .

\section{Hasil per Penambahan Baru (Yield Per Recruit=Y/R)}

Hasil per penambahan baru diperoleh berdasarkan parameter pertumbuhan (K) sebesar 0,293 tahun ${ }^{-1}$, laju kematian alami sebesar 0,47 tahun $^{-1}$, ukuran rata- rata pertama kali tertangkap (LC) sebesar $38,1 \mathrm{~cm}$, ukuran saat penambahan baru ( $\mathrm{Lr}$ ) yang diperoleh dari ukuran terkecil ikan yang tertangkap sebesar $30 \mathrm{~cm}$, ukuran panjang asimptotik $\left(\mathrm{L}_{\infty}\right)$ sebesar $77,3 \mathrm{~cm}$ dan berat asimptotik $\left(\mathrm{W}_{\infty}\right)$ sebesar $4.612 \mathrm{gr}$ yang diperoleh berdasarkan hubungan panjang-berat $\mathrm{W}=0,00001 \mathrm{~L}^{2,9997}$. Hasil per penambahan baru ikan kakap merah (L. malabaricus) menunjukkan peningkatan hingga titik maksimum yaitu saat laju kematian karena penangkapan $\left(F_{\text {max }}\right)$ sebesar 1,2 tahun $^{-1}$ dan hasil per penambahan baru $\left(Y / R_{\max }\right)$ sebesar $469 \mathrm{gr} \mathrm{rekrut}^{-1}$ dan menyisakan biomasa per rekrut $15 \%$ dari biomasa awal (Bv), kemudian hasil per penambahan baru menurun setelah mencapai titik maksimum (Gambar 6). Koefien kematian karena penangkapan saat ini $\left(\mathrm{F}_{\text {cur }}\right)$ adalah 0,25 tahun $^{-1}$ dengan hasil penambahan baru saat ini $\left(Y / R_{\text {cur }}\right)$ sebesar 340 gr rekrut (Tabel 1).

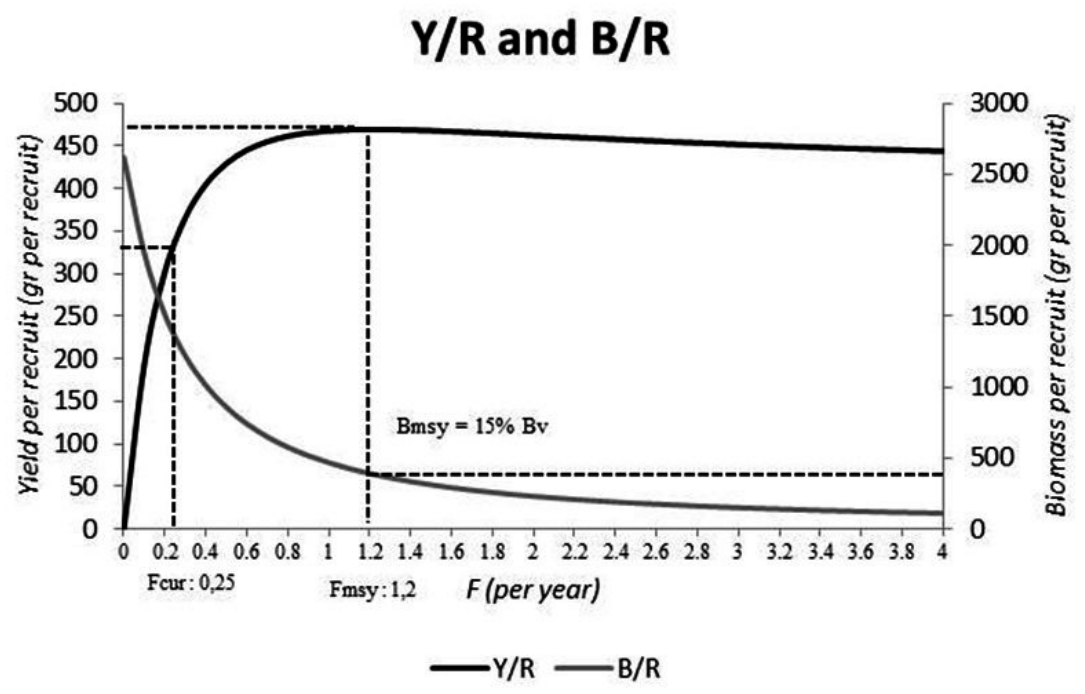

Gambar 6. Kurva hasil per penambahan baru dan biomassa per penambahan baru ikan kakap merah ( $L$. malabaricus) tertangkap di perairan Sinjai dan sekitarnya.

Figure 6. Yield per recruit and biomass per recruit curves of red snapper (L. malabaricus) caught in Sinjai waters and adjacent.

Koefisien penangkapan saat ini $\left(\mathrm{F}_{\text {cur }}\right)$ di perairan Sinjai dan sekitarnya sebesar 0,25 tahun $^{-1}$ belum melebihi koefisien penangkapan maksimum $\left(\mathrm{F}_{\max }\right)$ yaitu sebesar 1,2 $\operatorname{tahun}^{-1}$ (Gambar 5). Kondisi tersebut menunjukkan tingkat pemanfaatan ikan kakap merah di perairan Sinjai dan sekitarnya belum berada dalam kondisi lebih tangkap.

Koefisien kematian $F_{0,1}$ sebesar 0,9 tahun $^{-1}$ merupakan titik acuan optimum ikan kakap merah yang disarankan di perairan Sinjai dan sekitarnya berdasarkan analisis hasil per penambahan baru. Koefisien kematian karena penangkapan saat ini $\left(\mathrm{F}_{\text {cur }}\right)$ sebesar 0,25 tahun ${ }^{-1}$ lebih kecil dibandingkan titik acuan $\mathrm{F}_{0,1}$ sebesar 0,9 tahun ${ }^{-1}$ menunjukkan tingkat pemanfaatannya masih tergolong lestari (sustainable).

\section{Estimasi Rasio Potensi Pemijahan (Spawning Potential Ratio=SPR)}

Estimasi rasio potensi pemijahan ikan kakap merah diperoleh berdasarkan rasio laju kematian alami dengan pertumbuhan $(\mathrm{M} / \mathrm{K})$ sebesar 1,6 , panjang asimptotik $\left(\mathrm{L}_{\infty}\right)$ sebesar $77,3 \mathrm{~cm}$, panjang saat $50 \%$ populasi ikan matang gonad (Lm) sebesar $45,6 \mathrm{~cm}$ dan panjang saat $95 \%$ populasi ikan matang gonad $\left(L_{95}\right)$ sebesar $59,8 \mathrm{~cm}$. Estimasi rasio potensi pemijahan ikan kakap merah di perairan Sinjai dan sekitarnya adalah $51 \%$ (Tabel 2). Kondisi tersebut menunjukkan terdapat sekitar $51 \%$ populasi ikan kakap yang tersisa di alam akan melakukan pemijahan. 
Tabel 1. Laju kematian penangkapan dan titik acuan ikan kakap merah (L. malabaricus) tertangkap di perairan Sinjai dan sekitarnya.

Table 1. Fishing mortality and reference points of red snapper (L. malabaricus) caught in Sinjai Waters and adjacent.

\begin{tabular}{cccc}
\hline Parameter & $\mathbf{F}_{\max }$ & $\mathbf{F}_{0,1}$ & $\mathbf{F}_{\text {cur }}$ \\
\hline $\mathrm{F}\left(\right.$ tahun $\left.^{-1}\right)$ & 1.20 & 0.90 & 0.25 \\
$\mathrm{Y} / \mathrm{R}(\mathrm{gr} / \mathrm{r})$ & 469.4 & 465.4 & 340.4 \\
$\mathrm{~B} / \mathrm{R}(\mathrm{gr} / \mathrm{r})$ & 391.1 & 519.5 & 1341.4 \\
\hline
\end{tabular}

Tabel 2. Potensi rasio pemijahan ikan kakap merah (L. malabaricus) tertangkap di perairan Sinjai dan sekitarnya

Table 2. Spawning potential ratio (SPR) of red snapper (L. malabaricus) caught in Sinjai Waters and adjacent

\section{Parameter}

$\mathrm{SL}_{50}(\mathrm{~cm})$
$\mathrm{SL}_{95}(\mathrm{~cm})$
$\mathrm{Lm}_{50}(\mathrm{~cm})$
$\operatorname{Lm}_{95}(\mathrm{~cm})$

$\mathrm{F} / \mathrm{M}$

SPR (\%)

\section{Estimasi}

\section{Estimated}

38,1

49,2

45.6

59.8

0,54

51
Rasio potensi pemijahan ikan kakap merah di perairan Sinjai dan sekitarnya sebesar $51 \%$ pada panjang rata-rata $48,17 \mathrm{cmTL}$, lebih tinggi dibandingkan ambang batas minimum (threshold) rasio potensi pemijahan berdasarkan Prince (2014) sebesar $20 \%$ dan berdasarkan ambang batas minimum ikan kakap merah menurut GMFMC (2015) sebesar $26 \%$. Kondisi tersebut menunjukkan tingkat pemanfaatan ikan kakap merah di perairan Sinjai dan sekitarnya masih tergolong lestari atau belum mengalami lebih tangkap.

\section{Bahasan}

Ukuran ikan kakap merah (Lutjanus malabaricus Schneider, 1801) yang tertangkap di perairan Sinjai dan sekitarnya tergolong cukup besar berkisar antara 30-74 cm, tidak jauh berbeda dengan ikan yang tertangkap rawai dasar dan jaring insang di perairan Barru, Sulawesi Selatan di tahun 2010 dengan ukuran ikan kakap merah antara $33-70 \mathrm{~cm}$ (Sumiono et al., 2010). Ukuran ikan yang relatif besar di perairan Sinjai disebabkan oleh alat tangkap rawai dasar yang masih tergolong ramah lingkungan karena memiliki tingkat selektifitas tinggi. Ukuran panjang asimptotik ikan kakap di daerah penelitian sebesar $77,3 \mathrm{~cm}$ lebih tinggi dibandingkan di perairan Kalimantan Selatan sebesar $57,8 \mathrm{~cm}$ dan Australia sebesar 68,6 cm (Prihatiningsih \& Wahyuningsih, 2012; Newman, 2002). Perbedaan ukuran ikan kakap merah di beberapa lokasi perairan dapat disebabkan oleh perbedaan habitat, perbedaan alat tangkap dan tekanan penangkapan. Tekanan penangkapan yang semakin tinggi dapat menyebabkan ukuran ikan tertangkap lebih kecil (Ricker, 1981). Tekanan penangkapan ikan di perairan Sinjai dan sekitarnya diduga belum mempengaruhi struktur ukuran populasi ikan kakap merah sehingga ukuran ikan yang tertangkap tergolong cukup besar.

Laju pertumbuhan (K) ikan kakap merah di perairan Sinjai dan sekitarnya sebesar 0,293 tahun $^{-1}$, tidak jauh berbeda dengan laju pertumbuhan ikan kakap merah di perairan lainnya di wilayah Indonesia dan Australia dengan rentang laju pertumbuhan berkisar 0,18-0,3 tahun $^{-1}$ (Tabel 3). Laju pertumbuhan ikan kakap merah tergolong rendah menunjukkan ikan kakap merah memiliki umur yang cukup panjang. Ikan kakap merah di daerah penelitian mencapai ukuran maksimum diduga pada umur 10 tahun. Ikan kakap merah ( $L$. malabaricus) di perairan teluk Persia sebesar $71 \mathrm{~cm}$ diduga dicapai pada umur sekitar 7 tahun (Soleiman et al., 2013). Ikan kakap merah (L. malabaricus) diduga dapat hidup mencapai umur lebih dari 20 tahun (Newman et al., 2000). Karena umur ikan kakap merah yang relatif panjang maka penangkapannya sebaiknya dilakukan pada ikan yang memiliki ukuran cukup besar yaitu menunggu ikan berukuran lebih besar dari ukuran rata-rata pertama kali matang gonadnya $(\mathrm{Lm})$ agar pertumbuhan populasinya dapat terus berlangsung. 
Tabel 3. Panjang asimptotik $\left(\mathrm{L}_{\infty}\right)$ dan laju pertumbuhan $(\mathrm{K})$ ikan kakap merah (L. malabaricus) tertangkap di perairan Sinjai dan sekitarnya dan beberapa lokasi lainnya

Table 3. Asimptotic length $\left(L_{\infty}\right)$ and growth rate $(K)$ of rate snapper ( $L$. malabaricus) caught in Sinjai waters and adjacent and other sampling sites

\begin{tabular}{lccl}
\hline $\begin{array}{l}\text { Lokasi } \\
\text { Location }\end{array}$ & $\mathbf{L}_{\infty}$ & K & $\begin{array}{l}\text { Pengarang } \\
\text { Authors }\end{array}$ \\
\hline Australia & $68,64 \mathrm{cmFL}$ & 0,18 & Newman, 2002 \\
Laut Jawa, Indonesia & $97,65 \mathrm{cmFL}$ & 0,22 & Wahyuningsih et al., 2013 \\
Utara Arafura, Indonesia & $55,3 \mathrm{cmSL}$ & 0,3 & Fry et al., 2009 \\
Kalimantan Selatan, Indonesia & $57,86 \mathrm{cmFL}$ & 0,238 & Prihatiningsih \& Wahyuningsih, 2012 \\
Sinjai, Indonesia & $77.3 \mathrm{cmTL}$ & 0,293 & Penelitian ini \\
\hline
\end{tabular}

Ukuran rata-rata pertama kali matang gonad (Lm) ikan kakap merah betina di perairan Sinjai dan sekitarnya adalah $45,6 \mathrm{cmTL}$. Ukuran rata-rata pertama kali matang gonad $(\mathrm{Lm})$ merupakan salah satu indikator tekanan penangkapan (Lappalainen et al., 2016). Ukuran rata-rata pertama kali matang gonad $(\mathrm{Lm})$ lebih besar dibandingkan selektivitas alat tangkap (LC) untuk rawai dasar sebesar $38,1 \mathrm{~cm}$ menunjukkan sebagian besar ikan tertangkap sebelum melakukan pemijahan sehingga disarankan untuk melakukan pembatasan ukuran dengan tidak menangkap ikan yang berukuran kurang dari $45 \mathrm{~cm}$.

Laju kematian total (Z), laju kematian alami (M) dan laju kematian karena penangkapan $(F)$ ikan kakap merah di daerah penelitian berturut-turut adalah 0,72 tahun $^{-1}, 0,47$ tahun $^{-1}$ dan 0,25 tahun $^{-1}$. Laju kematian total, laju kematian alami dan laju kematian penangkapan ikan kakap merah di Laut Jawa adalah 1,04 tahun ${ }^{-1}, 0,49$ tahun $^{-1}$ dan 0,55 tahun ${ }^{-1}$ (Wahyuningsih et al., 2013). Laju kematian total, laju kematian alami dan laju kematian penangkapan ikan kakap merah di Arafura adalah 1,41 tahun ${ }^{-1}, 0,27$ tahun $^{-1}$ dan 1,14 tahun $^{-1}$ (Sadhotomo \& Suprapto, 2013). Laju kematian total dan laju kematian penangkapan ikan kakap merah di daerah penelitian lebih kecil dibandingkan di perairan laut Jawa dan Arafura disebabkan perbedaan alat tangkap dan tekanan penangkapan. Laju pengusahaan (E) ikan kakap merah di perairan Sinjai adalah 0,35. Tingkat pemanfaatan yang optimum berdasarkan Gulland (1983) adalah 0,5 sehingga tingkat pemanfaatan ikan kakap merah masih berada di bawah titik optimum dan tergolong lestari (sustainable). Pengusahaan ikan kakap merah di perairan Sinjai dan sekitarnya berdasarkan laju pengusahaan saat ini sebesar 0,35 dan titik optimum sebesar 0,5 , dapat dikembangkan sekitar $30 \%$ dari upaya saat ini dengan disertai kehatihatian dengan pembatasan ukuran tertangkap.
Hasil per penambahan baru ikan kakap merah saat ini dengan ukuran rata-rata pertama kali tertangkap (LC) rawai dasar $38,1 \mathrm{~cm}$ adalah 340,4 gr per rekrut, dicapai saat laju kematian karena penangkapan (F) sebesar 0,25 tahun $^{-1}$. Hasil per penambahan baru pada prinsipnya adalah fungsi dari F sebagai bentuk dari upaya dan Lc sebagai selektivitas alat tangkap (Beverton \& Holt, 1957; Sparre \& Venema, 1992). Titik acuan yang dihasilkan dari model hasil per penambahan baru adalah upaya maksimum $\left(\mathrm{F}_{\max }\right)$ dan upaya saat hasil sama dengan $10 \%$ dari biomasa awal $\left(F_{0,1}\right)$. Peningkatan upaya penangkapan ikan kakap merah di perairan Sinjai dan sekitarnya akan meningkatkan hasil per penambahan baru hingga mencapai titik maksimum $\left(\mathrm{F}_{\max }\right)$ sebesar 1,2 tahun $^{-1}$ dan kemudian hasil per penambahan baru akan mengalami penurunan setelah tercapai upaya maksimum. Upaya penangkapan kakap merah saat ini sebesar 0,25 tahun ${ }^{-1}$ lebih kecil dari titik acuan $F_{\max }$ sebesar 1,2 tahun $^{-1}$ dan $F_{0,1}$ sebesar 0,9 tahun $^{-1}$ menunjukkan upaya penangkapan kakap merah yang masih dapat dikembangkan di perairan Sinjai dan sekitarnya namun diperlukan monitoring ketat dan penuh kehati-hatian.

Rasio potensi pemijahan didefinisikan sebagai sisa proporsi ikan tidak tertangkap yang berpotensi melakukan pemijahan di bawah tekanan penangkapan (Mace \& Sissenwine, 1993; Walters \& Martell, 2004; Prince et al., 2015). Estimasi rasio potensi pemijahan ikan kakap merah di perairan Sinjai dan sekitarnya diperoleh sebesar $51 \%$ menunjukkan terdapat sekitar $51 \%$ populasi ikan tidak tertangkap yang berpotensi melakukan pemijahan. Rasio potensi pemijahan akan mengalami penurunan ketika tekanan penangkapan semakin meningkat (Goodyear, 1993). Titik referensi SPR untuk ikan kakap merah menurut GMFMC (2015) adalah $26 \%$ sebagai ambang batas minimum dan titik referensi target sebesar $36 \%$. Titik referensi SPR 
menurut Prince (2014) adalah $20 \%$ sebagai ambang batas minimum dan titik referensi target sebesar $40 \%$. Rasio potensi pemijahan ikan kakap merah di perairan Sinjai lebih besar dari titik referensi minimum dan titik referensi target menunjukkan pengusahaannya yang masih tergolong lestari (sustainable) sehingga pengembangan upaya masih dapat dilakukan.

\section{KESIMPULAN}

Ikan kakap merah yang tertangkap di perairan Sinjai dan sekitarnya memiliki ukuran panjang total ( Total Length $=T L$ ) berkisar antara $30-74 \mathrm{~cm}$ dengan panjang asimptotik adalah $77,3 \mathrm{~cm}$ dan laju pertumbuhan (K) 0,293 tahun $^{-1}$. Hasil per penambuhan baru ikan kakap merah saat ini adalah $340 \mathrm{gr} / \mathrm{r}$ saat laju penangkapan 0,25 tahun $^{-1}$ dan ukuran pertama tertangkap pancing dasar $38 \mathrm{~cm}$. Tingkat pemanfaatan saat ini adalah 0,35 tahun $^{-1}$ dan upaya penangkapan saat ini lebih kecil dibandingkan titik acuan yang disarankan $\left(F_{\text {cur }}=0,25, ; F_{\text {max }}=1,2 ; F_{0,1}=0,9\right)$, menunjukkan upaya penangkapan yang masih dapat dikembangkan. Estimasi rasio potensi pemijahan ikan kakap merah adalah 30\% lebih besar dari titik referensi minimum $26 \%$ dan titik referensi target $36 \%$. Pengelolaan yang disarankan berdasarkan penelitian ini adalah upaya penangkapan kakap merah di perairan Sinjai dan sekitarnya dapat dikembangkan 30\% dari upaya saat ini dengan diikuti pembatasan ukuran yang boleh tertangkap sebaiknya berukuran lebih besar dari ukuran rata-rata pertama matang gonad sebesar 45 $\mathrm{cm}$.

\section{PERSANTUNAN}

Tulisan ini merupakan bagian dari kegiatan penelitian "Karakteristik Biologi Perikanan, Potensi, Produksi dan Habitat Sumber Daya Ikan di perairan WPP 713" oleh Balai Penelitian Perikanan Laut, Muara Baru, Jakarta. Ucapan terima kasih disampaikan kepada enumerator yaitu Bapak Muhlis yang telah membantu pengumpulan data selama penelitian.

\section{DAFTAR PUSTAKA}

Beverton, R. J. H., \& Holt S. J. (1957). On the dynamics of exploited fish populations. Fish Invest. U.K. Ministry of Agriculture, Food and Fisheries, London. 533 p.

Cadima, EL. (2003). Fish Stock Assessment Manual (p. 161). FAO Fisheries Technical Paper No.393.

Chen, S., \& Watanabe, S. (1989). Age dependence of natural mortality coefficient in Fish population dynamics. Nippon Suisan Gakkaishi, 55(2), 205-208.
Direktorat Jenderal Perikanan Tangkap. (2015). Statistik Perikanan Tangkap Indonesia menurut Provinsi 2015. Direktorat Jenderal Perikanan Tangkap. 325 p.

FAO. (1998). The living marine resources of the Western Central Pacific Vol.2: Cephalopods, Crustaceans, Holothurians and Sharks. FAO Species Identification Guide for Fishery Purposes. Rome. 1.396 p.

Fry, G. C., \& Milton, D. A. (2009). Age, growth and mortality estimates for populations of red snappers Lutjanus erythropterus and L. malabaricus from Northern Australia and Eastern Indonesia. Fish. Sci, 75, 1219-1229.

GMFMC. (2015). Minimum stock size threshold (MSST) for reef fish stocks with low natural mortality. Gulf of MexicoFishery Management Council. NOAA. 17 pp.

Gold, J. R., Voelker, G., \& Renshaw, M. A. (2011). Phylogenetic relationships of tropical western Atlantic snappers in subfamily Lutjaninae (Lutjanidae: Perciformes) inferred from mitochondrial DNA sequences. Biological Journal of the Linnean Society, 102, 915-929.

Goodyear, C. P. (1993). Spawning stock biomass per recruit in fisheries management: foundation and current use. p. 67-81. In S. J. Smith, J.J. Hunt and D. Rivard (ed). Risk evaluation and biological reference points for fisheries management. Can. Spec. Publ. Fish. Aquat. Sci. 120 p.

Gulland, J. A. (1983). Fish stock assessment (p. 233). A Manual of Basic Method. Chicester: John Wiley and Sons.

Gulland, J. A., \& Boerema L. K. (1973). Scientific advice on catch level. Fishery Bulletin, 71(2), 325335.

Hordyk, A., Ono, K., Valencia, S., Loneragan, N., \& Prince, J. (2015). A novel length-based empirical estimation method of spawning potential ratio (SPR), and tests of its performance, for smallscale, data-poor fisheries. ICES Journal of Marine Science, 72(1), 217-231.

Kim. M. J., Kim, B. Y., Kim, J. S., \& Song, C. B. (2012). Two unrecorded species of the Snapper (Perciformes: Lutjanidae) collected from Jeju Island, Korea. Fisheries and Aquatic Sciences, 15(4), 313-316. 
King, M. (1995). Fishery biology, assessment and management (p. 341). United Kingdom: Fishing New Books.

Lappalainen, A., Saks, L., Sustar, M., Heikinheimo, O., Jurgens, K., Kokkonen, E., Kurkilahti, M., Verliin, A., Vetemaa, M. (2016). Length at maturity as a potential indicator of fishing pressure effects on coastal pikeperch (Sander lucioperca) stocks in the northern Baltic Sea. Fisheries Research, 174, 47-57.

Mace, P. M., \& Sissenwine, M. P. (1993). How much spawning per recruit is enough? In S.J. Smith, J.J. Hunt and D. Rivard (eds.) Risk evaluation and biological reference points for fisheries management. Canadian Special Publications in Fisheries and Aquatic Sciences, 120, 101-118.

Mildenberger, T. K., Taylor, M. H., Wolff, M. (2017). TropFishR: an R package for fisheries analysis with length-frequency data. Working paper. 19 pp.

Newman, S. J. (2002). Growth rate, age determination, natural mortality and production potential of the scarlet seaperch, Lutjanus malabaricus Schneider 1801, off the Pilbara Coast of NorthWestern Australia. Fisheries Research, 58, 215225.

Newman, S. J., Cappo, M., \& Williams, D. M. B. (2000). Age, growth, mortality rates and corresponding yield estimates using otoliths of the tropical red snappers, Lutjanus erythropterus, $L$. malabaricus and L. sebae, from the central Great Barrier Reef. Fisheries Research, 48, 1-14.

Pauly, D. (1983). Some simple methods for the assessment of tropical fish stocks. FAO Fisheries Tech. Rome. 52 p.

Prihatiningsih \& Wahyuningsih. (2012). Pertumbuhan, umur dan mortalitas ikan kakap merah (Lutjanus malabaricus) dari perairan Kotabaru (Pulau Laut) Kalimantan Selatan. Prosiding. Seminar Nasional Perikanan Tangkap. Manado. 373-383 p.

Prince, J. (2014). A Technical Report on an SPR@Size Assessment of Blue Swimmer Crab fishery in
Southeast Sulawesi. IMACS Project Report. USAID. Unpublished. $30 \mathrm{p}$.

Prince, J., Victor, S., Kloulchad, V., Hordyk, A. (2015). Length based SPR assessment of eleven IndoPacific coral reef fish populations in Palau. Fisheries Research, 171, 42-58.

Ricker, W. E. (1981). Changes in the average size and average age of pacific salmon. Canadian Journal of Fisheries and Aquatic Sciences, 38(12), 1636-1656 p.

Sadhotomo, B., \& Suprapto. (2013). Interaksi antar trawl dan rawai dasar pada perikanan kakap merah (Lutjanus malabaricus) di Laut Timor dan Arafura. J. Lit. Perikan. Ind, 19(2), 89-95.

Schaefer, M. B., \& Orange, C. I. (1956). Studies of the sexual development and spawning of yellowfin tuna Neothunnus macropterus and Skipjack Katsuwonus pelamis in three areas of the Eastern Pacific Ocean, by examination of gonads. InteAm. Trop. Tuna Com. Bull, 1(6), 283-349.

Soleiman, M.P., Valinasab, T., Ataiemehr, B., \& Kamali, E. (2013). Age determination of Lutjanus malabaricus by using otolith in Hormozgan Water (Persian Gulf, Hormozgan). Iranian Journal of Biology, 26(3): 305-313.

Sparre, P., \& Venema S. C. (1992). Introduction to Tropical Fish Stock Asseessment Part 1. Manual. Fao Fish. Tech. Pap. (306/1). Rev.1: 376 p.

Sumiono, B., Ernawati, T., \& Wedjatmiko. (2010). Analisis penangkapan kakap merah dan kerapu di perairan Barru, Sulawesi Selatan. J. Lit. Perikan. Ind, 16(4), 293-303.

Wahyuningsih., Prihatiningsih., \& Ernawati, T. (2013). Parameter populasi ikan kakap merah (Lutjanus malabaricus) di Perairan Laut Jawa Bagian Timur. BAWAL, 5(3), 175-179.

Walters, C., \& Martell, S. J. D. (2004). Fisheries Ecology and Management. Princeton University Press, Princeton, N J. 399 pp. 